\title{
Awareness about Melanoma in Biotechnology Students
}

\author{
Muhammad Imran Qadir* and Sidra Zafar \\ Bahauddin Zakariya University, Pakistan
}

*Corresponding author: Muhammad Imran Qadir, Institute of Molecular Biology and Biotechnology, Bahauddin Zakariya University, Multan, Pakistan Submission: 䟧 June 01, 2018; Published: 䟧July 17, 2018

\begin{abstract}
Most common type of cancer is melanoma which occurs abundantly worldwide. Melanin is a skin pigment that is produced by skin melanocytes in case or malignant melanoma that effects the melanocytes and then cause the faults in pigment production. The occurrence of melanoma is most common in people with light colored skin on exposure to sunlight as compared to darker ones. The basic purpose of this study was to determine the awareness among the biotechnology students about the melanoma. A questionnaire based on 15 questions about melanoma was developed and being fulfilled by postgraduate students. Survey shows that $81 \%$ of total students thought the major cause of melanoma is not virus. On average $56-67 \%$ students thought that melanoma is either a genetic disease or it arises due to metabolic problems. This survey among biotechnology students of M. Phil. shows that some are aware and some are not aware about melanoma.
\end{abstract}

Keywords:Telomerase; Topoisomerase; Telomeres; Quercetin

\section{Introduction}

Most common type of cancer is melanoma which occurs abundantly worldwide. Melanin is a skin pigment that is produced by skin melanocytes in case or malignant melanoma that effects the melanocytes and then cause the faults in pigment production. The occurrence of melanoma is most common in people with light colored skin on exposure to sunlight as compared to darker ones. Melanoma is caused by the mutation in CDKN2A and CDK4 genes. Chromosome $1(1 \mathrm{p} 22)$ and some other genes may be the cause of melanoma but it is still under observation [1]. In US alone, 1 person dies of melanoma in every 52 minutes. Besides, New Zealand and Australia are the top countries with highest death rate associated with melanoma patients. The statistics may become aggravated in future if ozone layer remains unrepaired or continues to deplete. When compared, there are far lesser studies conducted on melanoma and the use of gold nanoparticles than other types of cancers such as prostate, breast, lung cancers. As with other cancers, effective treatment strategies needs to be studied about melanoma due to the large no. of deaths associated with it which cannot be ignored [2]. The basic purpose of this study was to determine the awareness among the biotechnology students about the melanoma.

\section{Methodology}

A questionnaire based on 15 questions about melanoma was developed (Table 1). This questionnaire was distributed among 38 students of M. Phil. Biotechnology of Bahauddin Zakariya University Multan and being fulfilled by them. This survey is given in (Table 1).
Table 1: Questionnaire to evaluate awareness about etiology of Melanoma.

\begin{tabular}{|c|c|c|}
\hline Major Cause of Melanoma is & Yes & No \\
\hline \multicolumn{3}{|l|}{ 1. Viral disease } \\
\hline \multicolumn{3}{|l|}{ 2. Bacterial disease } \\
\hline \multicolumn{3}{|l|}{ 3. Fungal disease } \\
\hline \multicolumn{3}{|l|}{ 4. Genetic disease } \\
\hline \multicolumn{3}{|l|}{ 5. Metabolic disease } \\
\hline \multicolumn{3}{|l|}{ Ever Suffered from Melanoma } \\
\hline \multicolumn{3}{|l|}{ 6. You } \\
\hline \multicolumn{3}{|l|}{ 7. Your family } \\
\hline \multicolumn{3}{|l|}{ 8. Your relative } \\
\hline \multicolumn{3}{|l|}{ 9. Your neighbor } \\
\hline \multicolumn{3}{|l|}{ 10. Your friend } \\
\hline \multicolumn{3}{|l|}{ Mode of Transmission of Melanoma } \\
\hline \multicolumn{3}{|l|}{ 11. Contacts or blood transfusion } \\
\hline \multicolumn{3}{|l|}{ 12. From parents to offspring } \\
\hline \multicolumn{3}{|l|}{ Possible Treatment of Melanoma } \\
\hline \multicolumn{3}{|l|}{ 13. Medicines } \\
\hline \multicolumn{3}{|l|}{ 14. Surgery } \\
\hline 15. Do not worry, it is easily curable & & \\
\hline
\end{tabular}




\section{Result and Discussion}

Awareness of postgraduate students about etiology of the melanoma is given in (Table 2). Survey shows that $81 \%$ of total students thought the major cause of melanoma is not virus. On average 56$67 \%$ students thought that melanoma is either a genetic disease or it arises due to metabolic problems. Almost $100 \%$ of students said that the never encounter melanoma in their family and relatives. 30-40\% students thought the transmission of melanoma is inher- ited.91\% of students thought medicine is the effective treatment of melanoma and 54\% students thought that surgery is also an effective treatment. Previous studies show that 3 Survey of skin diseases in Asian people among 9273 children, the 11 most common diagnoses were eczema (49.3\%), viral infections (6.5\%), pigmentation disorders $(5.5 \%)$, bacterial infections $(4.9 \%)$, parasitic infections $(3.8 \%)$, urticaria $(3.8 \%)$, acne vulgaris $(3.1 \%)$, fungal infections (2.5\%), alopecias (1.8\%), and psoriasis (1.1\%). Most common disease in Asian people is Eczema [3].

Table 2: Awareness about etiology of Melanoma: views of postgraduate biology students.

\begin{tabular}{|c|c|c|c|c|c|c|}
\hline \multirow{2}{*}{ Questions } & \multicolumn{2}{|c|}{ Male } & \multicolumn{2}{|c|}{ Female } & \multicolumn{2}{|c|}{ Total } \\
\hline & Yes & No & Yes & No & Yes & No \\
\hline \multicolumn{7}{|c|}{ Major cause of Melanoma } \\
\hline 1. Viral disease & $0 \%$ & $100 \%$ & $37.50 \%$ & $62.50 \%$ & $18.75 \%$ & $81.25 \%$ \\
\hline 2. Bacterial disease & $0 \%$ & $100 \%$ & $18.75 \%$ & $81.25 \%$ & $9.38 \%$ & $90.63 \%$ \\
\hline 3. Fungal disease & $0 \%$ & $100 \%$ & $21.87 \%$ & $78.13 \%$ & $10.93 \%$ & $89.05 \%$ \\
\hline 4. Genetic disease & $66 \%$ & $34 \%$ & $46.87 \%$ & $53.13 \%$ & $56.43 \%$ & 43.56 \\
\hline 5. Metabolic disease & $66 \%$ & $34 \%$ & $68.75 \%$ & $31.25 \%$ & $67.37 \%$ & 32.62 \\
\hline \multicolumn{7}{|c|}{ Ever suffered from Melanoma } \\
\hline 6. You & $0 \%$ & $100 \%$ & $0 \%$ & $100 \%$ & $0 \%$ & 100 \\
\hline 7. Your family & $0 \%$ & $100 \%$ & $0 \%$ & $100 \%$ & $0 \%$ & 100 \\
\hline 8. Your relative & $0 \%$ & $100 \%$ & $0 \%$ & $100 \%$ & $0 \%$ & 100 \\
\hline 9. Your neighbor & $16.66 \%$ & $83.34 \%$ & $0 \%$ & $100 \%$ & $8.33 \%$ & 91.67 \\
\hline 10. Your friend & $0 \%$ & $100 \%$ & $0 \%$ & $100 \%$ & $0 \%$ & 100 \\
\hline \multicolumn{7}{|c|}{ Mode of transmission of Melanoma } \\
\hline 11. Contacts or blood transfusion & $0 \%$ & $100 \%$ & $6.25 \%$ & $93.75 \%$ & $3.12 \%$ & 96.87 \\
\hline 12. From parents to offspring & $16.66 \%$ & $83.34 \%$ & $46.87 \%$ & $53.12 \%$ & $31.76 \%$ & 68.23 \\
\hline \multicolumn{7}{|c|}{ Possible Treatment of Melanoma } \\
\hline 13. Medicines & $83.33 \%$ & $16.67 \%$ & $100 \%$ & $0 \%$ & $91.66 \%$ & 8.33 \\
\hline 14. Surgery & $33.33 \%$ & $66.67 \%$ & $75 \%$ & $25 \%$ & $54 \%$ & $45 \%$ \\
\hline 15. Do not worry, it is easily curable & $83.33 \%$ & $16.67 \%$ & $25 \%$ & $75 \%$ & $54 \%$ & $45 \%$ \\
\hline
\end{tabular}

\section{Conclusion}

This survey among biotechnology students of M. Phil. shows that some are aware and some are not aware about melanoma, while some are fully aware and others are not fully aware about melanoma.

\section{References}

1. Orthaber K, Pristovnik M, Skok K, Perić B, Maver U (2017) Skin cancer and its treatment: novel treatment approaches with emphasis on nanotechnology. Journal of Nanomaterials 2017: 1-20.
2. Siegel RL, Miller KD, Jemal A (2016) Cancer statistics, 2016. Cancer J Clin 66(1): 7-30

3. Taylor SC (2003) Epidemiology of skin diseases in people of color. Cutis 71(4): 271-275. 
Creative Commons Attribution 4.0 International License

For possible submissions Click Here

Submit Article

\section{Novel Approaches in Cancer Study}

Novel
Approaches
in Cancer Study

\section{Benefits of Publishing with us}

- High-level peer review and editorial services

- Freely accessible online immediately upon publication

- Authors retain the copyright to their work

- Licensing it under a Creative Commons license

- Visibility through different online platforms 